\title{
PENGEMBANGAN PARIWISATA YANG BERKELANJUTAN MELALUI EKOWISATA*
}

\author{
Oleh \\ Moh Agus Sutiarso \\ Ketua Lembaga Pengembangan Pariwisata \& Budaya (LPPB) Mitra Persada, Bali \\ Dosen Manajemen Kepariwisataan di Sekolah Tinggi Pariwisata Bali Internasional (STPBI) Denpasar-Bali
}

\begin{abstract}
Pengembangan pariwisata dilakukan dalam rangka meningkatkan pertumbuhan ekonomi masyarakat, dan merupakan usaha secara berencana dan terstruktur. Arah, kebijakan, strategi dan program pengembangan pariwisata harus dibuat selaras dan sinergi dengan arah kebijakan pembangunan kepariwisataan secara nasional, agar tidak menyimpang dari tujuan pembangunan kepariwisataan. Pengembangan pariwisata selayaknya mengiktui prinsipprinsip keberlanjutan, yang mengintegrasikan keberlanjutan ekologi, sosial dan ekonomi. Strategi pendekatan untuk pariwisata berkelanjutan ini disarankan berskala kecil, manajemen lokal, dan memberikan keuntungan kepada masyarakat banyak. Ekowisata selain memberi manfaat bagi masyarakat lokal juga memberi kontribusi langsung bagi kegiatan konservasi. Pengelolaan secara terpadu diperlukan dari tahap perencanaan, pelaksanaan, pemantauan dan evaluasi yang mampu mengintegrasikan semua kepentingan stakeholders.
\end{abstract}

Kata Kunci: pariwisata berkelanjutan, ekowisata

\section{PENDAHULUAN}

Pengembangan pariwisata merupakan salah satu bagian dari pembangunan ekonomi dalam rangka meningkatkan pertumbuhan ekonomi dalam suatu Negara. Sehingga dapat menciptakan lapangan kerja bagi masyarakat yang lebih luas yang nantinya dapat meningkatkan pendapatan masyarakat secara keseluruhan yang akhirnya dapat meningkatkan kemakmuran masyarakat.

Dalam pengembangan pariwisata suatu daerah, perlu memperhatikan potensi yang dimiliki oleh daerah yang bersangkutan. Makin banyak potensi yang ada dalam suatu daerah, makin layak daerah itu dikembangkan menjadi daerah tujuan wisata.

Dari aspek sosial, masyarakat yang ada di daerah bersangkutan memiliki karakter sosial yang adi luhung berupa keramah-tamahan dan mudah menerima siapa saja yang memasuki daerah mereka. Potensi soaial ini akan memudahkan untuk membentuk interaksi sosial yang lebih familiar dan dapat membangun hubungan kemanusaian yang lebih harmonis, disamping memiliki berbagai tradisi unik yang bisa dikemas menjadi produk wisata untuk dipromosikan.

Dari aspek budaya, di daerah yang bersangkutan memiliki berbagai karya seni dan peninggalan sejarah yang mempunyai nilai seni tinggi yang juga bisa dikemas menjadi produk wisata. 
Dari aspek alam, daerah yang bersangkutan memiliki potensi alam dengan keunikan dan keunggulan tersendiri. Keanekaragaman satwa endemik yang ada di daerah juga merupakan potensi yang bisa dibangun untuk dijadikan produk wisata. Potensi alam tersebut merupakan anugerah Tuhan yang patut disyukuri.

\section{PENGEMBANGAN PARIWISATA}

Pengembangan pariwisata merupakan suatu usaha secara berencana dan terstruktur untuk membenahi objek dan kawasan yang ada dan membangun objek dan kawasan wisata yang baru yang akan dipasarkan pada calon wisatawan. Pengembanngan pariwisata pada prinsipnya sama dengan pengembangan produk wisata, yang mana dalam pengembangan produk wisata yang merupakan sarana pariwisata hendaknya disesuaikan dengan perubahan selera wisatawan yang sangat dinamis. Untuk kemajuan pengembangan pariwisata, ada beberapa usaha yang perlu dilakukan secara terpadu dan dengan baik, yaitu:

1. Promosi untuk memperkenalkan objek dan kawasan wisata.

2. Transportasi yang lancar

3. Kemudahan keimigrasian atau birokrasi

4. Akomodasi yang menjamin penginapan yang nyaman

5. Pemandu wisata yang cakap

6. Penawaran barang barang dan jasa dengan mutu terjamin dan tarif harga yang wajar.

7. Pengisian waktu dengan atraksi-atraksi yang menarik

8. Kondisi kebersihan dan kesehatan lingkungan hidup.

\section{DAMPAK PARIWISATA}

Dalam pengembangan objek dan kawasan pariwisata perlu dianalisa dampak yang ditimbulkan baik dari segi positif dan negatifnya, sehingga kita dapat melihat manfaat dan resiko yang ditimbulkan yang bisa digunakan sebagai bahan pertimbangan. Secara teori dampak yang ditimbulkan dengan pengembangan pariwisata dapat dilihat dari pengaruh perkembangan pariwisata terhadap daerah tujuan wisata yang dapat dilihat dari tiga aspek.

\subsection{Aspek Ekonomi}

Dampak positif, meliputi:

a. Menambah kesempatan kerja, sehinga dapat mengurangi masalah pengangguran Industri pariwisata merupakan kegiatanmata rantai yang sangat panjang, sehingga banyak membuka lapangan kerja bagi masyarakat sekitarnya. 
b. Meningkatkan pendapatan Nasional, yang berarti pendapatan per kapita bertambah.

Pendapatan nasional merupakan akumulasi dari pendapatan masyarakat, dimana dengan adanya perkembangan pariwisata, maka pendapatan masyarakat akan bertambah dengan menjual barang dan jasa wisata, misal: restoran, hotel, biro perjalanan., pramuwisata, dan barang-barang souvenir.

c. Meningkatkan pendapatan pemerintah dari pajak Dengan bertambahnya pendapatan masyarakat, baik secara personal maupun melakukan kegiatan bisnis pariwisata akan dapat meningkatkan pajak yang dipungut oleh pemerintah

d. Memperkuat posisi Neraca Pembayaran Luar Negeri atau neraca pembayaran internasional.

Pariwisata merupakan ekspor yang tidak kentara, sehingga dengan adanya perkembangan pariwisata akan dapat meningkatkan ekspor negara yang bersangkutan ayang jelas akan memperbaiki neraca pembayaran internasional.

e. Meningkatkan penghasilan devisa bagi negara berkembang.

Dengan semakin banyaknya wisatawan asing yang datang ke Indonesia, maka akan semakin banyak devisa yang diterima.

f. Merupakan basis pertumbuhan bagi korporasi transnasional.

g. Injeksi pendapatan ke perekonomian lokal melalui efek multiplier

h. Membantu eksistensi bisnis lokal

i. Mendorong peningkatan investasi dari sektor industri pariwisata dan sektor lainnya.

j. Mendorong pembanguan daerah dan pedesaan, memperbaiki daerah perkotaan, dan mendiversifikasi perekonomian lokal.

k. Menjamin produk pariwisata dibayar dengan harga pantas.

I. Meningkatkan produk hasil kebudayaan, karena meningkatnya konsumsi oleh para wisatawan.

m. Menyebarkan pemerataan pendapatan penduduk dunia dan nasional

n. Memperluas pasaran barang-barang yang dihasilkan dalam negeri

o. Dapat berakibat ganda terhadap sektor lain, seperti sektor pertanian dan sektor industri.

\section{Dampak negatinya, meliputi:}

a. Banyak pekerjaan dibayar murah dan musiman

b. Terjadinya penganguran infrastruktur pada waktu musim tertentu

c. Ketergantungan yang berlebihan pada pariwisata membuat perekonomian lokal goyah terhadap perubahan pasar pariwisata.

d. Pariwisata ikut menikmati subsidi yang diberikan pemerintah pemerintah. 
e. Terjadinya kebocoran ekonomi terutama adanya impor tenaga kerja top management sektor pariwisata dengan tarif gaji internasional dan fasilitas hotel yang berstandar internasional.

f. Terjadinya ketimpangan antara daerah tujuan wisata dengan daerah yang bukan tujuan wisata demikian juga antara obyek atau kawasan wisata dengan luar wisata.

g. Harga tanah menjadi mahal, begitu juga harga bahan makanan tertama di daerah kawasan pariwisata dan sekitarnya yang ada kecendrungan orang suka menjualnya.

h. Terjadinya urbanisasi dari desa ke daerah kawasan pariwisata yang menyebabkan bertambah sesaknya kawasan pariwisata.

\subsection{Aspek Sosial Budaya}

\section{Dampak positif, meliputi:}

a. Menggairahkan perkembangan kebudayaan asli dan menghidupkan kembali unsur kebudayaan yang sudah hampir terlupakan.

b. Meningkatkan kreaktivitas seni budaya masyarakat daerah tujuan wisata.

c. Meningkatkan kualitas warisan budaya.

d. Meningkatkan usaha pelestarian bahasa tradisional

e. Berkembangnya pasar kerajinan tradisional.

f. Berkembangnya bentuk \& desain kerajinan tradisional.

g. Meningkatnya pemahanan tentang gaya hidup bangsa-bangsa lain di dunia.

h. Adopsi nilai dan prilaku positif dari wisatawan ( perlakuan terhadap binatang ).

i. Pariwisata dapat meningkatkan kesehatan masyarakat

j. Pengalaman bergaul dan bekerja dengan orang dari masyarakat luar.

k. Pariwisata dapat menghilangkan prasangka dan kepicikan dan membantu terciptanya saling pengertian antara penduduk yang datang dengan penduduk yang dikunjungi.

\section{Dampak negatif, meliputi:}

a. Bangunan tidak lagi bergaya tradisional.

b. Tekanan terhadap bahasa tradisional

c. Menurunnya eksistensi produk budaya seperti terjadinya penggantian produksi lokal dengan produk yang merupakan budaya wisatwan.

d. Berubahnya gaya hidup masyarakat terutama berkembangnya pola hidup konsumtif.

e. Hilangnya kepercayaan masyarakat, terutama harga diri, karena sebagai pelayan wisatawan.

f. Meningkatnya tindak kejahatan, prostitusi dan tindak kriminal lainnya.

g. Terjadinya dominasi oleh masyarakat asing.

h. Terjadinya komersialisasi benda-benda sakral. 
i. Munculnya industri seks yang akan merusak moral masyarakat.

j. Berubahnya tujuan kesenian dan upacara tradisional.

k. Merosotnya mutu barang kerajinan, karena dikerjakan secara tergesa-gesa akibat permintaan yang banyak yang mendesak.

I. Terjadinya pemalsuan benda-benda budaya (mafia benda budaya), seperti: lukisan dan keramik.

m. Terjadinya demonstration effect (bergaya hidup mewah), kepribadian anak muda rusak, seperti cara berpakian mereka yang senonoh, contohnya bercelana kedodoran.

\subsection{Aspek Lingkungan}

\section{Dampak positif, meliputi:}

a. Meningkatkan usaha pemerintah melakukan konservasi terhadap lingkungan alam, marga satwa dan lingkungan pertanian.

b. Meningkatkan restorasi terhadap situs dan bangunan bersejarah.

c. Perbaikan manajemen lingkungan daerah pariwiwsata.

d. Meningkatkan penyediaan infrastruktur baru dan perbaikan infrastruktur yang telah ada.

e. Perubahan karakter areal bangunan melalui perluasan dan penataan kota.

f. Perubahan struktur atau tata ruang perkotaan dan pedesaan.

g. Meningkatkan perhatian pemerintan dan masyarakat terhadap usaha kebersihan lingkungan.

\section{Dampak negatif, meliputi:}

a. Menimbulkan polusi air, udara, suara dan tanah

b. Meningkatnya erosi yang berupa: abrasi pantai, tanah longsor, kerusakan geologi, dan kerusakan tepi sungai.

c. Pengurasan sumber air bawah dan atas tanah.

d. Pengurasan sumber mineral untuk material bangunan.

e. Eksploitasi berlebihan terhadap sumber biologikal.

f. Meningkatnya resiko kebakaran.

g. Munculnya perbedaan yang mencolok antara daerah untuk wisatawan dengan daerah penduduk setempat.

h. Infrastruktur overload.seperti tejadinya kemacetan lalu lintas.

i. Terjadinya penumpukan sampah dan limbah yang merusak ekosistem di sekitarnya.

j. Terjadinya kerusakan terumbu karang oleh tangan usil, karena permintaan semakin banyak.

k. Terjadinya perambahan hutan dimana-mana yang merusak habitat fauna dan menyebabkan tanah longsor. 
Melihat dampak yang ditimbulkan dari kajian teori, dimana dari ketiga aspek yang digunakan sebagai dasar kajian, selain manfaat yang diperoleh, namun tidak dapat dihindari terjadinya berbagai ekses negatif yang merupakan biaya, kerugian, dan kerusakan yang ditimbulkan terhadap daerah tujuan wisata baik dari ekonomi, sosial-budaya, dan lingkungan.

Untuk mengatasi atau meminimalkan dampak negatif dari pariwisata terhadap daerah tujuan wisata, maka diperlukan manajemen terpadu atau pengelolaan terpadu objek dan kawasan wisata dengan melibatkan semua stakeholder, disamping adanya kebijaksanaan yang komprehensif dan dikuti dengan law enforcement yang konsisten.

\section{KONSEP SUSTAINABLE DEVELOPMENT DAN SUSTAINABLE TOURISM DEVELOPMENT}

Pada 1980, International Union for the Conservation of Nature (IUCN), United Nations Environment Programme (UNEP), dan World Wildlife Fund (WWF) mengeluarkan sebuah "World Conservation Strategy", strategi konservasi dunia, untuk mencapai 3 (tiga) tujuan pokok yaitu:

1. Mempertahankan proses-proses ekologi yang esensial dan system pendukungnya.

2. Memelihara keanekaragaman genetik.

3. Menjamin penggunaan ekosistem dan spesiesnya secara berkelanjutan.

(IUCN, 1980).

Pada tahun 1987, Komisi Sedunia tentang Lingkungan Hidup dan Pembangunan (World Commision on Environment and Development) yang banyak dikenal sebagai komisi Brundtlandt (nama ketua komisi tersebut) menyatakan argumentasinya bahwa lingkungan dan pembangunan masa kini yang terjadi tidak berkelanjutan dan bahwa diperlukan tindakantindakan baru yang menjamin keberlanjutan dunia untuk masa mendatang.

Sebagai tema sentral, komisi Brundtlandt mendefinisikan istilah Sustainable Development (SD) sebagai "pembangunan yang berusaha memenuhi kebutuhan sekarang tanpa mengurangi kemampuan generasi yang akan datang untuk memenuhi kebutuhan mereka" (Soemarwoto, 2001).

Secara spesifik Grundy (1993) menyebutkan bahwa konsep Sustainable Development terdiri dari 3 (tiga) elemen system yang menyangkut:

1. Keberlanjutan ekologi

2. Keberlanjutan social, dan

3. Keberlanjutan ekonomi 
Konsep Sustainable Development kemudian oleh Burns dan Holden (1997) diadaptasi untuk bidang pariwisata sebagai sebuah model yang mengintegrasikan lingkungan fisik (place), lingkungan budaya (host community) dan wisatawan (visitor).

Adapun prinsip-prinsip yang menjadi acuan dalam Sustainable Tourism Development ini menurut Burns dan Holden (1997) terdiri dari:

1. Lingkungan memiliki nilai hakiki yang juga bisa sebagai asset pariwisata. Pemanfaatannya bukan hanya untuk kepentingan pendek, namun juga untuk kepentingan generasi mendatang.

2. Pariwisata harus diperkenalkan sebagai aktivitas yang positif dengan memberikan keuntungan bersama kepada masyarakat, lingkungan dan wisatawan itu sendiri.

3. Hubungan antara pariwisata dan lingkungan harus dikelola sehingga lingkungan tersebut berkelanjutan untuk jangka panjang. Pariwisata harus tidak merusak sumber daya, masih dapat dinikmati oleh generasi mendatang atau membawa dampak yang dapat diterima.

4. Aktivitas pariwisata dan pembangunan harus peduli terhadap skala/ukuran, alam, dan karakter tempat dimana kegiatan tersebut dilakukan.

5. Pada lokasi lainnya, keharmonisan harus dibangun antara kebutuhan-kebutuhan wisatawan, tempat/lingkungan, dan masyarakat lokal.

6. Dalam dunia yang dinamis dan penuh dengan perubahan, dapat selalu memberikan keuntungan. Adaptasi terhadap perubahan, bagaimanapun juga, jangan sampai keluar dari prinsip-prinsip ini.

7. Industri pariwisata, pemerintah lokal dan Lembaga Swadaya Masyarakat (LSM) pemerhati lingkungan semuanya memiliki tugas untuk peduli pada prinsip-prinsip tersebut di atas dan bekerja bersama untuk merealisasikannya.

Strategi pendekatan untuk pariwisata berkelanjutan ini oleh France (1997) disarankan berskala kecil, manajemen lokal, dan memberikan keuntungan kepada masyarakat banyak.

\section{PENGELOLAAN EKOWISATA BERKELANJUTAN}

Sistem pengelolaan ekowisata secara terpadu diperlukan untuk membangun ekowisata yang berkelanjutan dan berbasis masyarakat. Sistem ini melibatkan adanya sistem perencanaan, pelaksanaan, pemantauan dan evaluasi yang mampu mengintegrasikan semua kepentingan stakeholders, seperti: pemerintah, masyarakat lokal, pelaku bisnis, peneliti, akademisi, wisatawan maupun LSM.

Tanggung jawab masing-masing stakeholders bervariasi. Pemerintah bertanggung jawab dalam koordinasi pembuatan perencanaan, pembuatan kebijakan-peraturan, zonasi, dan pembangunan lokasi ekowisata tersebut. Selain itu, pemerintah juga bertanggung jawab 
untuk pembangunan infrastruktur seperti pembangunan jalan, sarana telekomunikasi, sarana air bersih, dan system pembuangan sampah.

Stakeholders lain juga memiliki tanggung jawab masing-masing yang sesuai dengan prinsip bahwa perencanaan harus juga memperhatikan dampak negatif yang mungkin timbul dari kegiatan ekowisata, baik secara ekonomi, ekologi maupun sosial budaya. Selain itu perencanaan juga harus dapat memberikan rambu-rambu agar manfaat kegiatan ekowisata dapat dinikmati secara optimal oleh semua pihak dan dampak negatif dapat diminimalkan.

Dari aspek ekologi, perencanaan pengukuran daya dukung lingkungan sangat penting sebelum lokasi dikembangkan menjadi kawasan ekowisata. Daya dukung lingkungan akan mempresentasikan kemampuan lingkungan untuk mendukung kegiatan ekowisata seperti penyediaan air bersih, penataan lahan dan keanekaragaman hayati yang dimiliki daerah ekowisata. Daya dukung lingkungan untuk pariwisata akan berkaitan dengan jumlah wisatawan yang dapat berkunjung ke lokasi ekowisata tersebut, fasilitas ekowisata yang dapat dibangun dan masalah sampah yang muncul dari kegiatan ekowisata. Selain itu, bahan material yang dipergunakan dalam pembangunan fasilitas wisata merupakan produk lokal dan tidak dalam intensitas yang sangat besar.

Secara ekonomis, suatu perencanaan pengembangan ekowisata harus memasukkan perhitungan biaya manfaat dari pengembangan ekowisata. Dalam perhitungan biaya dan manfaat (Cost Benefit Analysis) tidak hanya dijelaskan keuntungan ekonomis yang akan diterima oleh pihak terkait namun juga biaya yang harus ditanggung seperti biaya konservasi atau preservasi lingkungan. Tentu saja jangka waktu yang diperhitungkan dalam perhitungan dapat bervariasi sesuai dengan kesepakatan semua stakeholders yang terkait.

Sedangkan secara sosial budaya, perencanaan harus memasukkan kondisi sosial budya lokal masyarakat yang dapat dikembangkan dalam kegiatan ekowisata serta kemungkinan dampak negatif yang akan diterima dan cara mengatasinya.

Keberhasilan ekowisata tergantung pada beberapa hal, yang dapat dibagi menjadi tiga faktor utama yaitu faktor internal, eksternal dan struktural. Faktor internal dapat diklasifikasikan seperti potensi daerah untuk pengembangan ekowisata, pengetahuan operator ekowisata tentang pelestarian lingkungan dan partisipasi penduduk lokal. Sedangkan faktor eksternal merupakan faktor kunci yang berasal dari luar lokasi ekowisata tersebut, seperti kesadaran wisatawan akan kelestarian lingkungan, kegiatan penelitian/pendidikan di wilayah ekowisata untuk kepentingan kelestarian lingkungan dan masyarakat lokal. Sedangkan faktor struktural adalah faktor yang berhubungan dengan kelembagaan, kebijakan dan regulasi pengelolaan kawasan ekowisata (tingkat lokal, daerah, nasional dan internasional). Ketiga faktor kunci keberhasilan ini di sisi lain dapat menjadi kendala bagi pengembangan ekowisata.

Untuk melaksanakan ekowisata diperlukan adanya operator wisata yang menurut Wood (2002) bertanggung jawab dalam: 
1. Menyediakan informasi sebelum perjalanan berkaitan dengan budaya dan lingkungan lokasi ekowisata (misalnya: pakaian dan perilaku yang sopan).

2. Melakukan briefing yang mendalam pada saat kedatangan termasuk informasi tentang kondisi geografis, social, politik dan beberapa kendala/tantangannya.

3. Menyediakan guide lokal yang terlatih.

4. Memberikan kesempatan untuk bertemu dan berinteraksi dengan penduduk lokal.

5. Membangun pengertian atas kehidupan sehari-hari dan tradisi penduduk lokal dan berbagai isu yang cocok untuk didiskusikan dalam interkasi dengan penduduk lokal.

6. Membuka kesempatan bagi LSM yang ingin berpartisipasi.

7. Mengatur agar semua tiket masuk harus dibayar penuh.

8. Menyediakan akomodasi yang ramah lingkungan (site-sensitive).

Sesuai karakteristiknya, operator wisata selain berfungsi sebagai pemandu wisata yang menyediakan informasi yang dibutuhkan wisatawan juga menyiapkan akomodasi yang ramah lingkungan (eco-lodge) sebagai akomodasi yang cocok bagi ekowisata.

Akomodasi ramah lingkungan dianggap merefleksikan inisiatif lokal dengan menerapkan desain lokal dan pemakaian bahan lokal. Akomodasi khusus yang dibangun ini mampu menghindari tekanan yang terlalu banyak bagi lingkungan dan relatif mudah dalam perawatannya. Selain itu, wisatawan akan lebih terkesan dengan suasana eksotik yang muncul dari akomodasi semacam ini. Wood (2002) mengemukakan karakteristik eco-lodge sebagai berikut:

1. Melindungi lingkungan alam dan budaya.

2. Memperkecil dampak negative dalam pembangunannya.

3. Dibangun sesuai dengan budaya lokal seperti bentuk dan warna.

4. Mempergunakan air dengan efisien.

5. Memiliki penanganan limbah.

6. Memakai energy yang ramah lingkungan.

7. Membuka peluang bagi masyarakat lokal untuk berinteraksi.

8. Menawarkan program pendidikan bagi operator, wisatawan maupun penduduk lokal tentang lingkungan alam dan budaya.

9. Berkontribusi pada pembangunan lokal yang berkelanjutan lewat program riset.

Selain itu, salah satu faktor penting lain yang termasuk dalam pengelola wisata adalah upaya pemberdayaan masyarakat. Hal ini penting agar masyarakat lokal dapat terlibat dalam kegiatan ekowisata dan memberi perbaikan tingkat kesejahteraan tanpa mengabaikan nilainilai sosial budaya setempat. Usaha pemberdayaan masyarakat lebih diarahkan agar masyarakat mampu membuat keputusan sendiri agar dalam pengembangan ekowisata mampu mempresentasikan inisiatifnya dalam hubungan dengan stakeholders lain. 
Kegiatan yang dapat dipergunakan untuk meningkatkan peran serta masyarakat diantaranya adalah usaha peningkatan kualitas sumberdaya manusia (capacity building). Upaya ini biasa dilakukan dalam bentuk pelatihan, penyuluhan-sosialisasi tentang konsep ekowisata, pembuatan uasaha kecil, pemandu wisata maupun pengelolaan akomodasi (ecolodge). Selain itu, usaha pemberdayaan masyarakat juga dapat dilakukan dalam bentuk pemberian kredit bagi masyarakat lokal agar dapat memulai usaha seperti membuka warung/café, pembuatan cendera mata, toko cendera mata maupun fasilitas ekowisata lain seperti penyewaan alat selam, penyewaan sepeda, dan penyewaan perahu/kano.

Dalam upaya pemberdayaan masyarakat penting untuk disosialisasikan bahwa kegiatan ekowisata selain memberi manfaat bagi masyarakat lokal juga harus memberi kontribusi langsung bagi kegiatan konservasi. Hal ini penting agar dalam mengembangkan usahanya, mereka memiliki rambu-rambu konservasi yang harus dijaga. Hubungan dengan stakeholders lain juga dapat saling bahu membahu untuk melaksanakan konservasi.

Untuk mencapai ekowisata yang berkelanjutan diperlukan monitoring dan evaluasi dari pelaksanaan ekowisata. Monitoring dan evaluasi dilakukan secara internal dan eksternal. Secara internal, monitoring ke dalam dilakukan oleh pengelola sendiri, sedang eksternal dilakukan oleh pihak luar seperti masyarakat, LSM dan lembaga independen lainnya.

\section{PENUTUP}

Arah, kebijakan, strategi dan program pengembangan ekowisata harus dibuat selaras dan sinergi dengan arah kebijakan pembangunan kepariwisataan secara nasional, agar tidak menyimpang dari tujuan pembangunan kepariwisataan nasional yaitu: 1) Meningkatkan kualitas dan kuantitas destinasi pariwisata, 2) Mengkomunikasikan destinasi pariwisata Indonesia dengan menggunakan media pemasaran secara efektif, efisien, dan bertanggung jawab, 3) Mewujudkan industri pariwisata yang mampu menggerakkan perekonomian nasional, dan 4) Mengembangkan kelembagaan kapriwisataan dan tata kelola pariwisata yang mampu mensinergikan pembangunan destinasi pariwisata, pemasaran wisata, dan industri pariwisata secara profesional, efektif dan efisien.

Diharapkan melalui pelaksanaan program-program pembangunan kepariwisataan yang dibuat, pembangunan daerah dan kesejahteraan masyarakat di sekitar kawasan akan meningkat. Sehingga dapat mewujudkan visi pembangunan kepariwisataan nasional yaitu terwujudnya Indonesia sebagai Negara tujuan wisata berkelas dunia, berdaya saing, berkelanjutan, mampu mendorong pembangunan daerah dan kesejahteraan rakyat.

Ada empat unsur utama yang mendukung terselenggaranya rencana pembangunan, yaitu: 1) Tersedianya perangkat hukum yang memadai, 2) Kesiapan aparat dan kelembagaan Pemerintah Daerah setempat, 3) Tersedianya dana yang cukup, dan 4) Dukungan masyarakat dalam mencapai tujuan. 


\section{DAFTAR PUSTAKA}

Boo, E. 1991. Making Ecotourism Sustainable: Recommendation for Planning, Development and Management. In: Whelan, T (Ed). Nature Tourism - Managing for the Environment. Island Press.

Burns, P.M. and A. Holden. 1997. Alternative and Sustainable Tourism Development - The Way Forward. In: France, L. (Ed). The Earthscan Reader in Sustainable Tourism. Earthscan. London.

Fandeli, C. 2000. Perencanaan Nasional Pengembangan Ekowisata. Dalam: Fandeli, C. dan Mukhlison (ed). Pengusahaan Ekowisata. Fakultas Kehutanan Universitas Gadjah Mada. Yogyakarta.

France, L. 1997. Principles of Sustaineble Tourism. In: France, L. (Ed). The Earthscan Reader in Sutainable Tourism. Earthscan. London.

Grundy, K.J. 1993. Sustainable Development - An Emerging Paradigm? Proceedings of the Seventeenth Conference, New Zealand Geographical Society Conference 1993. Christchurch. New Zealand.

IUCN. 1980. World Conservation Strategy. Living Reseources Conservation for Sustainable Development, IUCN, UNEP, WWF. Gland. Switzerland.

MacKinnon. J., K. MacKinnon, G. Child, and J. Thorsell. (Eds). 1986. Managing Protected Areas in the Tropics. IUCN, Gland. Switzerland.

Nasikun. 1999. Globalisasi dan Pembangunan Pariwisata Berbasis Komunitas. Makalah pada Lokakarya Penataran Pariwisata dalam Menyongsong Indonesia Baru. DepdagriPuspar UGM. Puncak. Jawa Barat.

Simatauw, M., L. Simanjuntak, P.T. Kuswardono. Gender dan Pengelolaan Sumber Daya Alam. Yayasan Pikul. Kupang. NTT.

Soemarwoto, Otto. 2001. Atur Diri Sendiri: Paradigma Baru Pengelolaan Lingkungan Hidup. Gadjah Mada University Press. Yogyakarta.

Sulthoni, A. 2000. Pengembangan Ekowisata dalam Kawasan Konservasi. Dalam: Fandeli, C dan Mukhlison (Ed). Pengusahaan Ekowisata. Fakultas Kehutanan Universitas Gadjah Mada. Yogyakarta.

Wearing, S and J. Neil. 2000. Ecotourism: Impacts, Potentials and Possibilities. ButterworthHeinemann. Oxford.

Wood, M.E. 2002. Ecotourism: Principles, Practices \& Policies for Sustainability. UNEP.

WTO/UNEP. 1992. Guidelines: Development of National Parks and Protected Area for Tourism.

*) Makalah disampaikan pada Focus Group Discussion (FGD) Pengelolaan Teluk Bone Bidang Pariwisata, Kolaka-Sulawesi Tenggara, 7 Maret 2017. 